\title{
ENSAIO SOBRE A NECESSIDADE DE UM PROCEDIMENTO ESPECIAL PARA A
} REPETIÇÃO DE INDÉBITO TRIBUTÁRIO

\author{
Felipe Coelho Teixeira ${ }^{1}$ \\ Lucas Nogueira Holanda ${ }^{2}$
}

\section{Resumo}

A pesquisa objetiva analisar meios processuais para a busca da repetição do indébito tributário no ordenamento brasileiro, especificamente no processo judicial, abordando, a ação de repetição de indébito e o mandado de segurança, entendidas como principais medidas positivadas aceitas pela jurisprudência para efetivar a restituição tributária. Buscar-se-á estabelecer comparação entre os instrumentos, explorando peculiaridades, vantagens e desvantagens, além dos princípios aplicáveis ao processo tributário. Pretende-se demonstrar viabilidade na criação de procedimento especial para regular a repetição de indébito tributário, mediante adoção de medidas que conferiram maior efetividade aos processos judiciais de restituição, sem descuidar da observância ao modelo constitucional processual.

Palavras-chave: Indébito Tributário; Restituição; Procedimento Especial; Processo Tributário.

\section{ESSAY ON THE NEED FOR A SPECIAL PROCEDURE FOR JUDICIAL TAX RESTITUTION}

\begin{abstract}
This research aims analyzing procedural means on seeking tax restitution in Brazilian legal system, specifically on judicial process, approaching ordinary tax recovery procedure and writ of mandamus, both as procedural measures stipulated by law and accepted by jurisprudence to effect tax restitution. It was sought to establish a comparison between these instruments types, exploring peculiarities, advantages and disadvantages, aside the principles applied to tax procedure. It is intended to demonstrate the viability on creating a special procedure to regulate the judicial tax restitution, by measures that bring greater effectiveness to tax restitution, without neglecting the observance of constitutional procedure model.
\end{abstract}

Keywords: Tax Undue; Refund; Special Procedure; Tax Lawsuit.

\section{INTRODUÇÃO}

Após o término da Segunda Guerra Mundial, observou-se o surgimento de

\footnotetext{
${ }^{1}$ Mestrando em Direito pela Unichristus e professor do Instituto de Pós-graduação e Graduação - IPOG. Advogado e sócio do Autran Nunes \& Teixeira Advogados. E-mail: felipe@ant.adv.br

${ }^{2}$ Mestrando em Direito Constitucional pela Universidade Federal do Ceará (UFC). Especialista em Direito e Processo Tributário pela Universidade de Fortaleza (Unifor). Advogado Tributarista. E-mail: lucasholandaadv@gmail.com
} 
diversas Constituições garantistas ao redor do mundo, marcando o início da era do neoconstitucionalismo (ou constitucionalismo pós-moderno) ${ }^{3}$, que tem, como principal característica, a concepção da Constituição como um instrumento de garantia de liberdades.

Esse novo modelo inaugura a necessidade de todo o ordenamento jurídico se amoldar à Constituição, incluindo o direito processual, que passou a ter sua validade condicionada à observância do processo de constitucionalização (DOS SANTOS, 2019).

O processo civil brasileiro foi desenvolvido com base na Constituição Federal e estrita observância de seus princípios, pelo que é possível constatar a adoção, no Brasil, de um modelo constitucional de processo civil. Trata-se, portanto, de um modelo baseado na proteção de direitos e garantias fundamentais, tais como o contraditório e a ampla defesa, a inafastabilidade da jurisdição e a duração razoável do processo.

Se o processo civil adota um modelo constitucional, é possível dizer que o processo tributário também o faz. Primeiro porque todo o ordenamento jurídico deve observar os princípios, direitos e garantias previstos na Constituição; segundo porque não existe um direito processual específico para lides tributárias, ou seja, “o processo judicial tributário é, em quase toda a sua extensão, o mesmo processo civil no qual são solucionadas as lides de uma maneira geral" (SEGUNDO, 2017, p. 65).

O Código Tributário Nacional - recepcionado pela Constituição com o status de lei complementar - prevê a possibilidade de o contribuinte que tenha recolhido um tributo de forma indevida (a maior) pleiteie a sua restituição, de acordo com o artigo $165^{4}$. Essa restituição pode se dar, basicamente, por 2 vias $^{5}$ : a) administrativa; b) judicial.

\footnotetext{
${ }^{3}$ Ao traçar o conceito de neoconstitucionalismo, Gilmar Mendes e Paulo Gustavo Branco ressaltam, com propriedade, que "O instante atual é marcado pela superioridade da Constituição, a que se subordinam todos os poderes por ela constituídos, garantida por mecanismos jurisdicionais de controle de constitucionalidade. A Constituição, além disso, se caracteriza pela absorção de valores morais e políticos (fenômeno por vezes designado como materialização da Constituição), sobretudo em um sistema de direitos fundamentais autoaplicáveis. Tudo isso sem prejuízo de se continuar a afirmar a ideia de que o poder deriva do povo, que se manifesta ordinariamente por seus representantes. A esse conjunto de fatores vários autores, sobretudo na Espanha e na América Latina, dão o nome de neoconstitucionalismo". (MENDES, Gilmar Ferreira; BRANCO, Paulo Gustavo Gonet. Curso de Direito Constitucional. 12. ed. São Paulo: Saraiva, 2017. p. 65)

${ }^{4}$ “O sujeito passivo tem direito, independentemente de prévio protesto, à restituição total ou parcial do tributo, seja qual for a modalidade do seu pagamento", em caso de "cobrança ou pagamento espontâneo de tributo indevido ou maior que o devido em face da legislação tributária aplicável".

${ }^{5}$ Parte da doutrina ainda considera uma terceira via, chamada de extraestatal. Nesse caso, o contribuinte restitui o tributo por meio de uma compensação, realizada por sua conta risco, por meio do ajuste de suas obrigações acessórias. Essa sistemática "acarreta num encontro de contas, tendo como resultado a extinção de duas obrigações contrapostas: relação jurídica tributária, em que o contribuinte tem débito perante o fisco; e restituição jurídica de restituição de indébito, na qual o contribuinte tem direito a crédito a ser pago pelo Fisco, até o limite que se equivalerem (art. 170 do CTN). Há, portanto, concomitantemente pagamento de tributo e
} 
O presente artigo explorará o processo de restituição do indébito tributário na esfera judicial (processo judicial tributário), a partir da concepção do modelo constitucional de processo. O objetivo é investigar se, mesmo com a observância de princípios e garantias constitucionais do processo, seria possível viabilizar um procedimento especial para a repetição do indébito tributário, como forma de garantir a efetividade e duração mais célere aos feitos que se prestam para o fim de restituir tributos.

\section{ADEQUAÇÃO DO PROCESSO CIVIL E DO PROCESSO TRIBUTÁRIO AO MODELO CONSTITUCIONAL}

O processo se apresenta como instrumento instituído pelo Estado para viabilizar o exercício da função jurisdicional. Portanto, é "por meio do processo, iniciado pelo direito de ação, que o cidadão pode se valer do Poder Judiciário para fiel observância dos direitos e garantias" (DANTAS, 2018, p. 24). É possível afirmar, dessa forma, que o processo possui fundamento constitucional, na medida em que é a Constituição que confere poderes ao Judiciário e garante os direitos de ação e defesa aos jurisdicionados, materializando o devido processo legal (DANTAS, 2018, p. 27).

Quando se trata de "processo constitucional", é comum remeter-se à seara dos processos indicados e regulamentados pela Constituição (remédios constitucionais, controle de constitucionalidade, etc.). Contudo, não é sob esse prisma que o presente artigo pretende abordar o chamado processo constitucional, e sim sob a perspectiva do processo enquanto garantia fundamental.

O modelo constitucional de processo tem como objetivo implementar, na seara processual - independente de qual seja ela - os direitos e garantias fundamentais previstos na Constituição. Em se tratando de direito processual, "os princípios, ao lado das garantias, são de indiscutível importância, como, aliás, em todas as disciplinas do direito público, porque emanam da Constituição" (NUNES, 2020, p. 116). Segundo as premissas desse modelo constitucional, todo processo deve seguir as diretrizes constitucionais, tratando-se, assim de "um modelo único de processo identificado nas Constituições dos Estados Democráticos de Direito e estruturado basicamente sobre os princípios processuais constitucionais" (DOS SANTOS,

restituição do indébito". (LAURENTIIS, Thais de. Restituição de Tributo Inconstitucional. São Paulo: Noesis, 2015. p. 271) 
2019, p. 79). A preocupação do legislador com a constitucionalização do processo pode ser percebida no próprio Código de Processo Civil de 2015, que, logo em seu primeiro artigo, aduz que "o processo civil será ordenado, disciplinado e interpretado conforme os valores e as normas fundamentais estabelecidos na Constituição da República Federativa do Brasil”.

O modelo constitucional de processo está construído exatamente sobre esses valores. Um processo constitucionalmente adequado, portanto, é aquele que prima pelos princípios processuais insculpidos na constituição, tais como: devido processo legal (que tem como um de seus corolários o princípio da efetividade), isonomia, juiz natural, inafastabilidade da jurisdição, motivação das decisões judiciais, do contraditório e ampla defesa e da duração razoável do processo (CÂMARA, 2017, p. 56).

Como o objeto central do presente artigo é a repetição do indébito tributário (sob o enfoque do direito processual), serão abordados princípios constitucionais inerentes ao processo civil, que podem ser igualmente aplicados ao processo judicial tributário, que se define como "conjunto de ações judiciais do processo civil na defesa dos interesses da Fazenda e dos contribuintes" (NUNES, 2020, p. 70).

Apesar do processo judicial tributário ser regulado por normas do Código de Processo Civil, observa-se que a legislação tributária não teve a mesma evolução da legislação processual, notadamente no que tange à efetividade e instrumentalidade do processo, princípios consagrados no Código de Processo Civil de 2015 (VERGUERO, 2016). É o que se passa a demonstrar nos tópicos a seguir.

\section{REPETIÇÃO DO INDÉBITO TRIBUTÁRIO E VIAS PROCESSUAIS ADEQUADAS}

A restituição do tributo encontra seus fundamentos nos princípios do direito à propriedade e do não confisco. Se o tributo foi recolhido sem fundamento constitucional ou legal, é forçosa a ilação de que deve ser restituído de ofício pelo ente que indevidamente dele se apropriou sem justo direito (MACHADO, 2015). Conclui-se, igualmente, que um tributo cobrado sem fundamento jurídico assume caráter confiscatório, resultando em enriquecimento ilícito por parte do Estado (BERNO, 2015).

O que corriqueiramente se observa é que a Administração Pública, além de não devolver de ofício o tributo, impõe todas as complicações possíveis quando o contribuinte pleiteia a restituição, seja na esfera administrativa, seja na judicial. No âmbito administrativo, 
os pedidos levam longos anos para serem analisados, muitas vezes fazendo com que o direito à restituição seja atingido pela prescrição durante o trâmite do processo administrativo ${ }^{6}$. Na esfera judicial, o Estado se utiliza de todos os recursos para protelar o desfecho da demanda, sejam esses recursos cabíveis ou não (MACHADO, 2015).

Não é apenas por meio da ação de repetição de indébito que se possibilita ao contribuinte pleitear, judicialmente, a devolução de um tributo indevidamente recolhido. $\mathrm{O}$ mandado de segurança igualmente se trata de ação frequentemente manejada com esse objetivo. Mas também a ação declaratória e a ação anulatória de débito fiscal - desde que cumuladas com pedido de repetição de indébito, podem servir para o fim de restituição (LAURENTIIS, 2015, p. 222-223).

O presente trabalho estará focado na análise dos dois principais instrumentos judiciais utilizados pelo contribuinte para a restituição tributária: a ação de repetição de indébito (procedimento comum) e o mandado de segurança (procedimento especial).

No que tange à ação de repetição de indébito, a lei não lhe atribuiu um rito próprio ou específico, tratando-se de procedimento comum, nela se admitindo, portanto, ampla dilação probatória. Para Fazzalari, o processo "ordinário" de cognição é o "arquétipo dos processos jurisdicionais civis, o modelo mais complexo e melhor regulado, o modelo no qual os outros processos de cognição são baseados" (2006, p. 159). O doutrinador italiano prossegue com suas lições, afirmando que "no curso do processo, partes e juiz não se ocupam somente do mérito, mas também - já ressaltamos - das atividades que pouco a pouco desenvolvem e constituem o processo: podem por isso surgir, antes da questão de mérito, questões "processuais" ou de "rito" (2006, p. 164).

Pelo exposto acima, logo se percebe que o procedimento comum possui a tendência de ser maior e mais complexo, podendo não dialogar com os princípios da efetividade processual e da duração razoável do processo (que alguns doutrinadores

\footnotetext{
${ }^{6}$ O Código Tributário Nacional prevê, em seu art. 168, I, que o contribuinte dispõe do prazo de cinco anos para pleitear judicialmente a restituição de um tributo indevidamente pago. Esse prazo tem como termo a quo exatamente da data do pagamento indevido. $O$ pedido administrativo de restituição não possui o condão de suspender ou interromper esse prazo, nos termos da Súmula 625 do Superior Tribunal de Justiça: "O pedido administrativo de compensação ou de restituição não interrompe o prazo prescricional para a ação de repetição de indébito tributário de que trata o art. 168 do CTN nem o da execução de título judicial contra a Fazenda Pública”. Dessa forma, o contribuinte que realiza um pleito administrativo de restituição não pode esperar demasiadamente por uma manifestação do fisco, sob pena de seu direito de pleitear judicialmente a restituição ser ceifado pela prescrição.
} 
denominam princípio da celeridade $\left.\operatorname{processual}^{7}\right)$.

O mandado de segurança, por sua vez, se trata de procedimento especial regulado por lei específica (12.016/2009). A ação mandamental visa a coibir atos abusivos e ilegais cometidos por autoridades públicas (SEGUNDO, 2017, p. 385). Trata-se de remédio constitucional $^{8}$ que possui diversas aplicações no âmbito do direito tributário: emissão de certidão negativa; liberação de mercadorias apreendidas em trânsito; reenquadramento em programas de parcelamento, etc. É comumente utilizado para a obtenção de medida judicial declaratória do direito de restituir tributos. Possui rito processual mais célere (característica típica dos procedimentos especiais) e, por tutelar direito líquido e certo, não admite dilação probatória, de modo que as provas devem ser pré-constituídas pelo impetrante. Isso significa dizer que, caso o fisco levante alguma matéria de ordem fática em suas informações, o mandado de segurança que busca o reconhecimento do direito de restituir tributos restará prejudicado, na medida em que não será permitida ao contribuinte a produção de provas (SEGUNDO, 2017, p. 386).

Com o manejo do mandado de segurança, objetiva-se, portanto, maior rapidez na solução do litígio, pois, como prevê a lei 12.016/2009, entre a apreciação da medida liminar e a sentença há tão somente a intervenção do Ministério Público (QUINTANILHA, 2016). Contudo, faz-se necessário observar que, mesmo nos casos em que o contribuinte pretende repetir o indébito tributário por meio de mandado de segurança - que deveria ser tratar de um procedimento mais célere -, os processos se arrastam por vários anos, às vezes décadas 9 .

Isso se explica, entre outras razões, pelo fato de ambas as espécies de ação ora em comento admitirem a interposição de recursos até o Supremo Tribunal Federal, caso o argumento que sustente o pleito de restituição esteja apoiado em questão constitucional e possua repercussão geral ${ }^{10}$. A possibilidade de o Estado recorrer a até três instâncias (tribunal

\footnotetext{
${ }^{7}$ Eduardo Rodrigues dos Santos, ao correlacionar duração razoável do processo com celeridade, preconiza que "a duração razoável do processo, isto é, a exigência de que os processos sejam julgados em tempo hábil fora positivada em nosso ordenamento, sobretudo, em razão da excessiva demora de nossos julgadores em proferir suas decisões, ou seja, da incapacidade/incompetência do Estado-juiz por fim aos conflitos sociais". (DOS SANTOS, op. cit. p. 182)

${ }^{8}$ É o que preconiza o art. 5., LXIX da Constituição Federal: “conceder-se-á mandado de segurança para proteger direito líquido e certo, não amparado por habeas corpus, ou habeas data, quando o responsável pela ilegalidade ou abuso de poder for autoridade pública ou agente de pessoa jurídica no exercício de atribuições do Poder Público".

${ }^{9}$ A emblemática tese da exclusão do ICMS da base do PIS/COFINS teve, como leading case, um processo oriundo do estado do Paraná. Apenas no STF, o feito (RE 574.706) vem se arrastando há mais de 13 (treze) anos.

${ }^{10}$ A Emenda Constitucional 45/2004 passou a exigir a demonstração de repercussão geral por parte do recorrente, como pré-requisito para a admissão do recurso extraordinário.
} 
de segunda instância, Superior Tribunal de Justiça e Supremo Tribunal), embora concretize o direito constitucional à ampla defesa, choca-se com o princípio da efetividade processual. Se a revisão da decisão por instâncias superiores é relevante para conferir maior segurança acerca da justiça da decisão, é igualmente verdade que, muitas vezes, essa gama de recursos previstos na legislação acaba por prestar um desserviço aos processos civil e tributário, pois retira do jurisdicionado a efetividade e a qualidade do provimento (MARINONI, 2020).

A Constituição Federal, ao assegurar aos litigantes o contraditório, a ampla defesa, e os recursos a ela inerentes, acabou abrindo o caminho para que o legislador processual previsse uma série de recursos e manifestações que acabam por tumultuar o andamento do processo. Alguns litigantes de fato se utilizam do sistema processual para procrastinar ao máximo o feito. Dentre esses litigantes mal intencionados, está o próprio Estado, muito em função de sua política fiscal expansionista, que visa a retardar ao máximo a devolução de valores indevidamente por ele arrecadados (VERGUERO, 2016). Se ao fisco é possibilitado recorrer a diversas instâncias do Judiciário, faz-se necessário encontrar um equilíbrio, ou seja, buscar um meio termo entre o direito ao contraditório e ampla defesa e a efetividade do processo judicial.

Um instrumento processual (aplicável a ambas as ações) que poderia promover esse equilíbrio, mitigando a morosidade própria da interposição desmedida de recursos é o cumprimento provisório de sentença. Todavia, via de regra ${ }^{11}$ não é possível a sua aplicação em desfavor da Fazenda Pública ${ }^{12}$. Essa limitação depõe contra o princípio da efetividade, ao eliminar a possibilidade de o contribuinte adiantar a prática de atos executivos.

Outro obstáculo imposto ao jurisdicionado que busca restituir judicialmente um tributo diz respeito à proibição de concessão de tutela provisória que autoriza a compensação de tributos. O Superior Tribunal de Justiça editou a Súmula $212^{13}$, ratificando a previsão

\footnotetext{
${ }^{11}$ Importante frisar a evolução da jurisprudência do Superior Tribunal de Justiça, que vem se consolidando no sentido de possibilitar a execução provisória contra a Fazenda Pública, mas apenas quando os valores forem incontroversos (REsp 1895295/PE, Rel. Ministra Assusete Magalhães, Segunda Turma, Julgado em 18/05/2021, DJe 24/05/2021).

12 "Segundo a atual previsão do art. 100 da CF, a expedição do precatório depende de a sentença ter transitado em julgado, passando a jurisprudência a entender que na hipótese de sentença condenatória de pagar quantia certa não caberá execução provisória contra a Fazenda Pública. E mesmo nas execuções de pequeno valor, que dispensam a expedição do precatório, a redação do art. 100, §3 $3^{\circ}$, da CF é suficientemente clara ao dispor sobre a exigência de a sentença ter transitado em julgado, o que também exclui a possibilidade de execução provisória". (NEVES, Daniel Amorim Assumpção. Manual de Direito Processual Civil. V. Único. 9. ed. Salvador: Juspodvim, 2017. p. 1.182)

${ }^{13}$ Súmula n. 212: A compensação de créditos tributários não pode ser deferida em ação cautelar ou por medida liminar cautelar ou antecipatória.
} 
contida no art. $7^{\circ}$., $\S 2^{\circ}$., da Lei do Mandado de Segurança (12.016/2009), que impossibilita a concessão de tutela provisória para a compensação de créditos tributários, por mais cristalino que seja o direito do contribuinte.

Essa impossibilidade de compensação antes do trânsito em julgado da ação foi apreciada em junho de 2021 pelo Supremo Tribunal Federal, no julgamento da ADI 4.296. Questionou-se exatamente a constitucionalidade do art. $7^{\circ}$., $\S 2^{\circ}$., da Lei do Mandado de Segurança (12.016/2009). Por ocasião do julgamento, a Corte Suprema declarou a inconstitucionalidade do referido dispositivo, para permitir a concessão de tutela provisória referente à compensação de créditos tributários.

Apesar de coerente a decisão do Supremo Tribunal Federal, é provável que o provimento não produza efeitos práticos, já que a proibição de compensação tributária antes do trânsito em julgado da ação está também inserida no art. 170-A do Código Tributário Nacional $^{14}$, dispositivo esse que permanece incólume. Destaque-se, ademais, que o art. 170-A do Código Tributário Nacional foi nele incluído em 2001, por meio da Lei Complementar 104. Antes disso, o legislador ordinário já havia tratado de regular a matéria no art. 74 , §12, II, "d" da lei 9.430/96, que considera não declarada a compensação na hipótese em que o crédito que a embasa seja decorrente de decisão judicial não transitada em julgado.

O contribuinte, em verdade, se encontra em posição duplamente desvantajosa: a) não poder restituir-se de tributos por meio de tutela antecipatória (seja em mandado de segurança, seja em ação de repetição de indébito), em função da vedação prevista no art. 170A do Código Tributário; b) via de regra, também não pode se utilizar da ferramenta do cumprimento provisório de sentença contra a Fazenda Pública, tendo que aguardar até o trânsito em julgado para ter acesso aos créditos reconhecidos em sentença (NEVES, 2017).

Os tratamentos diferentes dispensados às partes (Estado e contribuinte) afrontam o princípio da isonomia (ou da igualdade), o qual, apesar de não possuir conotação eminentemente processual, pode ser aplicado ao processo. O constituinte de fato prezou pelo tratamento igualitário de todos perante a lei, sem qualquer distinção ${ }^{15}$. Essa igualdade deve ser observada pelo legislador, pela administração pública e, evidentemente, pelo Poder Judiciário.

\footnotetext{
14 “Art. 170-A. É vedada a compensação mediante o aproveitamento de tributo, objeto de contestação judicial pelo sujeito passivo, antes do trânsito em julgado da respectiva decisão judicial".

${ }^{15}$ Assim prevê o art. $5^{\circ}$. da Constituição: "Todos são iguais perante a lei, sem distinção de qualquer natureza, garantindo-se aos brasileiros e aos estrangeiros residentes no País a inviolabilidade do direito à vida, à liberdade, à igualdade, à segurança e à propriedade [...]."
} 
No próprio Código de Processo Civil, é possível identificar dispositivos construídos com observância ao princípio da isonomia ${ }^{16}$.

\section{PROCEDIMENTO ESPECIAL DE REPETIÇÃO DE INDÉBITO TRIBUTÁRIO}

Muitas vezes, o procedimento comum não é capaz de solucionar todos os imbróglios de direito material que são apresentados ao Judiciário. Caso existisse apenas o procedimento comum para solucionar todas as situações, é certo que a tutela jurisdicional não seria oferecida com a qualidade desejada (NEVES, 2017).

Várias ações de cunho tributário - tanto de iniciativa do fisco quanto do contribuinte - são atualmente reguladas por meio de procedimentos especiais previstos em leis próprias: execução fiscal (lei 6.830/90), cautelar fiscal (lei 8.397/92), além do próprio mandado de segurança (lei 12.016/09). Esse último, muito embora não tenha sido concebido com o fito único e específico de regular matérias de cunho tributário, tem sido amplamente utilizado nesse ramo do direito, notadamente no que tange à restituição de tributo indevidamente pago.

Procedimentos especiais visam a tutelar situações particulares e estão "construídos com base em técnicas de cognição, sendo costumeiramente dotados de técnica antecipatória e meios executivos diferenciados" (MARINONI, 2020, p. 44). Dentre as técnicas de um procedimento especial, estão a "simplificação e agilização dos trâmites processuais, por meio da redução de prazos e eliminação de atos desnecessários" (DONIZETTI, 2017, p. 923). E é exatamente com base no princípio da eficiência e da duração razoável do processo que exsurge a ideia de um novo procedimento especial para a repetição do indébito tributário.

O princípio da eficiência ou da efetividade processual se trata de um corolário do devido processo legal. Um processo eficiente é aquele que "é instruído dentro de um prazo razoável, com um mínimo de custo possível, devendo ao final atingir a resposta "correta", conforme o direito e a justiça, garantindo à parte vencedora o desfrute efetivo do seu direito" (DOS SANTOS, 2019, p. 188). Tudo isso sem desrespeitar o modelo processual constitucionalmente estabelecido.

\footnotetext{
${ }^{16}$ Inicialmente no art. $7^{\circ} .:$ "É assegurada às partes paridade de tratamento em relação ao exercício de direitos e faculdades processuais, aos meios de defesa, aos ônus, aos deveres e à aplicação de sanções processuais, competindo ao juiz zelar pelo efetivo contraditório". A observância ao princípio da isonomia está igualmente explícita no art. 139, I, que reza que 'o juiz dirigirá o processo conforme as disposições deste Código, incumbindo-lhe assegurar às partes igualdade de tratamento".
} 
Coadunar com o entendimento de que o contribuinte pode aguardar por décadas para reaver valores indevidamente pagos significa concordar com a inefetividade do provimento jurisdicional, pois é possível que, uma vez concluído o processo judicial de restituição, o contribuinte (pessoa jurídica) já nem esteja mais desenvolvendo suas atividades, ou sequer esteja vivo (em se tratando de pessoa física). A duração desmesurada do processo judicial afeta, portanto, "não apenas e de forma direta a ideia de proteção judicial efetiva, como compromete de modo decisivo a proteção da dignidade da pessoa humana" (MENDES, 2017).

É importante ressaltar que não se está a defender a ideia de que o processo deve ser fulminante e sempre célere, pois "a duração do processo só pode ser considerada como razoável (ou não) quando no contexto do modelo constitucional de processo" (MARDEN, 2015, p. 114). Todavia, deve-se tomar cuidado para que essa constitucionalização em demasia não acabe por ceifar o próprio direito material perseguido por meio da jurisdição. A duração razoável do processo consta do próprio texto constitucional (art. 5., LXXVIII), tratando-se, portanto, de um "direito e garantia fundamental daqueles que são interessados na atividade jurisdicional" (MARDEN, 2015, p. 104). E, se não existe definição do que seria duração razoável, é possível afirmar que um processo que se estende por décadas não permite, na grande maioria das vezes, que a parte vitoriosa goze do resultado que alcançou com aquele provimento jurisdicional que lhe foi favorável.

A criação de um novo procedimento, além de não impossibilitar a existência do modelo constitucional de processo, prestigiaria o princípio da eficiência. Nos dizeres de Eduardo Rodrigues dos Santos:

[...] a própria Constituição, em respeito às particularidades de cada área do sistema jurídico, confere ao legislador infraconstitucional o dever de procedimentalizar cada ramo do direito processual buscando sua otimização (eficiência), evidentemente, respeitando-se o modelo por ela estabelecido (DOS SANTOS, 2019, p. 77).

Portanto, em observância aos princípios da efetividade processual e da duração razoável do processo, esse novo procedimento especial de repetição de indébito sobre o qual se debate deve ser inovador, prevendo, no mínimo: a) a possibilidade de cumprimento provisório do título judicial que condena a Fazenda Pública a pagar quantia certa; b) a possibilidade de compensação do crédito por meio de tutela provisória; c) o estabelecimento de prazos mais enxutos e eliminação de alguns atos.

\subsection{Cumprimento provisório de sentença contra a Fazenda Pública}


A primeira previsão proposta, ou seja, o cumprimento provisório de sentença, pode ser definido, resumidamente, como uma "execução fundada em título executivo judicial provisório, ou seja, a decisão judicial pode ser modificada ou anulada em razão da pendência de um recurso interposto contra ela" (NEVES, 2017, p. 1171). Para contextualizar a possibilidade de cumprimento provisório de sentença contra a Fazenda Pública, faz-se necessário repisar que, para ter acesso a valores relativos a tributos indevidamente pagos (reconhecidos em sentença judicial), o contribuinte pode se utilizar basicamente de dois mecanismos: a) restituição em dinheiro; 2) compensação ${ }^{17}$.

No caso da restituição, ela pode se dar por meio de precatório ou de RPV (Requisição de Pequeno Valor). Ambos, contudo, exigem o trânsito em julgado da ação para que possam ser expedidos, conforme se extrai do art. 100 da Constituição Federal ${ }^{18}$. Essa exigência escancara a atual impossibilidade de cumprimento provisório de títulos judiciais por quantia certa contra a Fazenda Pública, fazendo com que o contribuinte tenha que esperar até o trânsito em julgado da demanda para restituir-se em pecúnia. Nas lições de Humberto Theodoro Júnior:

Com a Emenda Constitucional $n^{\circ} 30$, de 13.09.2000, que deu nova redação ao $\S 1^{\circ}$ do art. 100 da CF/1988, ficou claro que, no caso de obrigação por quantia certa, a execução contra a Fazenda Pública, nos moldes do art. 534, somente será possível com base em sentença transitada em julgado, restando, pois, afastada, na espécie, a execução provisória. A Emenda n ${ }^{\circ}$ 62/2009 manteve igual orientação no texto renovado do atual $\S 5^{\circ}$ que continua prevendo que o regime de precatórios se aplica às "sentenças transitadas em julgado (THEODORO JÚNIOR, 2017, p. 220).

Diante de tantas limitações legais (inclusive de orçamento), constitucionais e doutrinárias, percebe-se, desde já, que seria complicado possibilitar, ao contribuinte, esse direito de restituição (em dinheiro) por meio de cumprimento provisório. A impossibilidade de execução provisória de sentença para as obrigações de pagar contra a Fazenda Pública é justificável, pois, caso houvesse essa permissão indiscriminada, o planejamento orçamentário dos

\footnotetext{
${ }^{17}$ A compensação devidamente homologada se trata de hipótese de extinção do crédito tributário, nos termos do art. 156, II, do Código Tributário Nacional.

${ }^{18}$ Art. 100. Os pagamentos devidos pelas Fazendas Públicas Federal, Estaduais, Distrital e Municipais, em virtude de sentença judiciária, far-se-ão exclusivamente na ordem cronológica de apresentação dos precatórios e à conta dos créditos respectivos, proibida a designação de casos ou de pessoas nas dotações orçamentárias e nos créditos adicionais abertos para este fim. [...] $\S 3^{\circ} \mathrm{O}$ disposto no caput deste artigo relativamente à expedição de precatórios não se aplica aos pagamentos de obrigações definidas em leis como de pequeno valor que as Fazendas referidas devam fazer em virtude de sentença judicial transitada em julgado. [...] $\S 5^{\circ}$ É obrigatória a inclusão, no orçamento das entidades de direito público, de verba necessária ao pagamento de seus débitos, oriundos de sentenças transitadas em julgado, constantes de precatórios judiciários apresentados até $1^{\circ}$ de julho, fazendo-se o pagamento até o final do exercício seguinte, quando terão seus valores atualizados monetariamente.
} 
entes federativos ficaria comprometido (PEIXOTO, 2018), porque "a inscrição em precatório geraria a obrigação de pagamento por parte do ente público (PEIXOTO, 2018, p. 85)”.

Porém, conforme já mencionado, a restituição em dinheiro não é a única alternativa disponível ao autor do pleito judicial de repetição de indébito tributário, podendo ele se utilizar também do instituto da compensação, nos moldes do art. 170 do Código Tributário. O problema é a disposição do art. 170-A do mesmo Código ${ }^{19}$, que desautoriza a referida compensação antes do trânsito em julgado da sentença judicial. Percebe-se que o legislador, ao estabelecer tal vedação, pressupôs que o indébito reconhecido judicialmente não possui liquidez (predicado quantitativo) e certeza (predicado qualitativo) antes do trânsito em julgado da ação (VERGUERO, 2016). Contudo, parte considerável da doutrina entende que essa previsão do art.170-A implica em "restrição desproporcional ao princípio que assegura a utilidade da prestação jurisdicional" (SEGUNDO, 2017, p. 387).

Portanto, esse novo procedimento deverá possibilitar ao contribuinte proceder ao cumprimento provisório do julgado, porém seu acesso ao crédito reconhecido em sentença não se daria por meio de restituição (precatório ou RPV), e sim através de compensação. Assim, o ente público não realizaria nenhuma espécie de desembolso financeiro, pois não haveria obrigação de pagamento no cumprimento provisório. Observar-se-ia apenas uma redução na arrecadação, em função da compensação operacionalizada pelo contribuinte.

\subsection{Tutela provisória autorizativa de compensação}

Além da possibilidade de cumprimento provisório de sentença, o procedimento especial de repetição de indébito que ora se propõe deverá permitir ao contribuinte obter tutela provisória que o autorize a proceder à compensação do crédito tributário, constatada a plausibilidade do seu pleito e o perigo de dano irreparável ou de difícil reparação.

Aliás, tal proposta se mostra alinhada ao já mencionado entendimento do Supremo Tribunal Federal na ADI 4.296, na qual restou declarada a inconstitucionalidade do art. $7^{\circ}$., $\S 2^{\circ}$., da Lei do Mandado de Segurança (12.016/2009), que vedava a concessão de tutela provisória referente à compensação de créditos tributários.

A lei que viesse a regular o procedimento deveria, ainda, revogar expressamente o

${ }^{19}$ Art. 170-A. É vedada a compensação mediante o aproveitamento de tributo, objeto de contestação judicial pelo sujeito passivo, antes do trânsito em julgado da respectiva decisão judicial. 
art. 170-A do Código Tributário Nacional, que impede a compensação antes do trânsito em julgado da ação de repetição de indébito. Assim, com a já declarada inconstitucionalidade do art. $7^{\circ}$., §2. ., da Lei do Mandado de Segurança (12.016/2009) e com a revogação do art. 170A do Código Tributário Nacional, o caminho para a compensação por meio de tutela provisória estaria definitivamente pavimentado, não sendo o contribuinte obrigado a aguardar até o trânsito em julgado da ação para poder compensar valores relativos a tributos indevidamente pagos. Com a revogação do art. 170-A ora proposta, os contribuintes que elegerem a via do procedimento comum (ação de repetição de indébito) ou a via do mandado de segurança também se beneficiarão.

Defende-se, em suma, a possibilidade de acesso mais célere do contribuinte ao crédito por meio de compensação, seja com base no cumprimento provisório de um título judicial, seja através de uma medida antecipatória concedida no decorrer do processo. Em ambos os casos, percebe-se a possibilidade de reversão: primeiro porque a sentença sobre qual se funda o cumprimento provisório pode ser reformada ou anulada; segundo porque a tutela provisória que autorizou a compensação pode ser cassada por uma instância superior, ou até mesmo ser reconsiderada pelo próprio juízo que a concedeu.

Em ocorrendo qualquer das situações de reversão ventiladas acima, a lei que regula o novo procedimento deverá prever tratamento similar ao já existente para a situação prevista no art. $63, \S 2^{\circ}$., da lei $9.430 / 96^{20}$. Esse dispositivo trata dos casos nos quais há cassação de medida liminar que autorizou o contribuinte a deixar de pagar determinada prestação tributária. A lei prevê que, enquanto estiver válida a medida liminar que dispensa o pagamento do tributo (ou autoriza seu pagamento a menor), o contribuinte não está em mora. Uma vez cassada a medida liminar, fica restabelecida a obrigação de pagamento do tributo, de forma retroativa ${ }^{21}$. Contudo, caso o contribuinte recolha o tributo (que passou a ser devido com a cassação da tutela provisória) no prazo de 30 (trinta) dias contados da data da publicação da decisão que reverteu a tutela antecipatória, poderá realizar o pagamento

\footnotetext{
${ }^{20}$ Art. 63. Na constituição de crédito tributário destinada a prevenir a decadência, relativo a tributo de competência da União, cuja exigibilidade houver sido suspensa na forma dos incisos IV e V do art. 151 da Lei no 5.172, de 25 de outubro de 1966, não caberá lançamento de multa de ofício. [...] $\S 2^{\circ}$ A interposição da ação judicial favorecida com a medida liminar interrompe a incidência da multa de mora, desde a concessão da medida judicial, até 30 dias após a data da publicação da decisão judicial que considerar devido o tributo ou contribuição.

21 "Com efeito, é decorrência natural do regime das medidas cautelares antecipatórias que a sua concessão se cumpra sob risco e responsabilidade de quem as requer, que a sua natureza é precária e que a sua revogação opera automáticos efeitos "ex tunc""'. (RE 608.482/RN, rel. min. Teori Zavascki, P, j. 7-8-2014, DJE de 30/10/2014).
} 
acompanhando apenas dos juros de mora, ou seja, sem a incidência de multa por atraso. Sobre o tema, Hugo de Brito Machado Segundo destaca, com notória propriedade:

$\mathrm{Na}$ verdade, o desaparecimento de uma liminar - seja por reconsideração, seja por reforma - enseja o retorno das partes à situação jurídica anterior à sua concessão. Se a liminar fora deferida, suspendendo a exigibilidade do crédito tributário, em momento no qual esse crédito ainda não se havia vencido, e por isso a multa moratória não era devida, o desaparecimento da liminar deve ensejar, para o contribuinte, a abertura de um prazo dentro do qual ainda poderá recolher, sem multas, o tributo cuja exigibilidade até então estava suspensa. Essa, aliás, é a orientação que prevalece na doutrina, e foi expressamente acolhida pelo legislador (2017, p. 425-426).

É exatamente essa linha de raciocínio que deverá ser aplicada no novo procedimento que se está a propor por meio do presente artigo. É certo que, seja por meio do cumprimento provisório do julgado, seja através do deferimento de tutela provisória, o contribuinte deixará de pagar tributos, pois efetivará compensação com o condão de extinguir o crédito tributário. Contudo, com a reforma da sentença ou cassação da tutela provisória, a compensação perderá seus efeitos, e os tributos (outrora extintos pela compensação) voltarão a ser devidos. Nesse caso, utilizando o mesmo princípio que se extrai do art. $63, \S 2^{\circ}$., da lei 9.430/96, contribuinte poderá proceder ao recolhimento desses tributos sem a incidência de multa de mora (apenas dos juros), desde que o faça dentro do prazo de 30 (trinta) dias, contados do provimento que reformar a sentença ou que cassar a tutela provisória.

Importante destacar que, para que possam ser implementadas essas novas medidas referentes à compensação - tanto em se tratando de cumprimento provisório de sentença, quanto de concessão de tutela provisória - a lei que regula esse novo procedimento deve prever regras gerais objetivas de compensação, aplicáveis a qualquer tributo e contra a Fazenda Pública de todos os entes. Atualmente, o art. 170 do CTN se trata de uma norma de eficácia contida, pois condiciona o direito de compensação à existência de legislação ordinária que a regule (estipulando critérios objetivos e condições) ${ }^{22}$. Ou seja, para realmente ter direito à compensação, o sujeito passivo precisa que o sujeito ativo do tributo a ser compensado tenha editado lei específica. A União Federal editou a lei para tal fim (8.383/91), porém nem todos os entes federativos assim procederam, possibilitando-lhes utilizar o argumento de

\footnotetext{
22 "A decisão agravada está de acordo com a jurisprudência desta Corte, que se firmou no sentido de que a compensação tributária só é autorizada quando observadas as regras fixadas na respectiva lei autorizativa, razão pela qual merece ser mantida. Acrescente-se que, nos termos do art. 170 do CTN, "a lei pode, nas condições e sob as garantias que estipular, ou cuja estipulação em cada caso atribuir à autoridade administrativa, autorizar a compensação de créditos tributários com créditos líquidos e certos, vencidos ou vincendos, do sujeito passivo contra a Fazenda pública"'”. (AgRg no REsp 1175542/RS, Rel. Ministro Mauro Campbell Marques, Segunda Turma, julgado em 05/08/2010, DJe 01/09/2010)
} 
inexistência de lei para refutar os pedidos de compensação efetivados pelos contribuintes (SEGUNDO, 2017).

A doutrina, no entanto, manifesta-se no sentido de que, em inexistindo legislação do Estado ou do Município que trate de compensação, seja possível aplicar, por analogia, o disciplinamento federal (8.383/91), ou ainda, o próprio Código Civil. Essa aplicação por analogia "impõe-se não apenas por autorização do CTN, mas por respeito à Constituição Federal" (SEGUNDO, 2017, p. 209), que fundamenta o direito de compensar. O novo procedimento de repetição de indébito proposto, ao traçar regras gerais de compensação válida para todo e qualquer ente, eliminará a chance de a compensação não acontecer por falta de legislação local autorizativa. Por tratar de compensação tributária (regra geral de direito tributário) e buscar vincular todos os entes tributantes, a lei que instaura o novo procedimento deve ser complementar, nos termos do art. 146, III da Constituição Federal.

Perceba-se que, muito embora as mudanças a serem trazidas pela nova legislação impactem diretamente no processo judicial tributário e, inclusive, em procedimentos administrativos (como no caso da compensação), é apenas por meio dessas alterações que se garantirá a efetividade do novo procedimento especial para a repetição do indébito tributário.

\subsection{Prazos mais enxutos e eliminação de atos}

É sabido que o Código de Processo Civil de 2015 estabelece prazos específicos e mais extensos para a Fazenda Pública. O Ministério Público e a Defensoria igualmente se beneficiam com o elastecimento de prazos processuais.

De fato, em seu art. 183, o CPC/2015 reza que a Fazenda Pública gozará de prazo em dobro para todas as suas manifestações processuais, assim como o Ministério Público (art. 180) e a Defensoria (art. 186). Entretanto, “não há contagem em dobro ser houver prazo próprio para o ente público estabelecido pela lei [...]" (PEIXOTO, 2018, p. 30), a exemplo do prazo de 10 (dez) dias para que a autoridade preste as informações em mandado de segurança (art. $\left.7^{\circ} . \mathrm{I}\right)$.

Não se pretende fingir o desconhecimento acerca do volume de trabalho da advocacia pública, nem da proteção do interesse público que justifica as prerrogativas processuais da Fazenda Pública (e nem esse é o objetivo do presente trabalho). Procura-se, em verdade, demonstrar que o contribuinte que busca reaver judicialmente um tributo 
indevidamente pago tem pressa, e com razão, pois o Estado está se apropriando de um valor que não lhe pertence.

Assim, o procedimento especial de repetição de indébito ora proposto deveria estabelecer um prazo de 5 (cinco) dias para a Fazenda Pública manifestar-se acerca do pleito realizado pelo contribuinte. Tal como no procedimento do mandado de segurança, deve o contribuinte demonstrar de plano seu direito, tornando desnecessária, portanto, a dilação probatória, favorecendo a celeridade do trâmite processual. Caso deseje produzir provas, o contribuinte continua tendo à sua disposição o procedimento comum para repetição de indébito previsto no Código de Processo Civil.

Ademais, ainda com objetivo de conferir celeridade ao novo procedimento, a oitiva do Ministério Público tornar-se-ia desnecessária (diferentemente do que expressamente prevê a lei do Mandado de Segurança), até mesmo porque na relação jurídico-tributária não se vislumbra interesse público primário, mas tão somente o interesse individual e disponível do autor da demanda. Aliás, o Ministério Público Federal vem continuamente se manifestando pela desnecessidade de sua intervenção em ações com o objetivo de repetir o indébito tributário, conforme se pode inferir de diversos pareceres emitidos pelo órgão ${ }^{23}$.

Essas pequenas (porém valiosas) medidas relacionadas à redução de prazos e eliminação de atos, somadas à possibilidade de cumprimento provisório de sentença e de concessão de tutela provisória para compensação de tributos, certamente conferem mais celeridade ao processo judicial de repetição de indébito tributário, prezando pela efetividade da tutela jurisdicional, sem descuidar das diretrizes do modelo constitucional de processo.

\section{CONCLUSÃO}

Em tempos de constitucionalização dos direitos, não há como negar que também o processo - em todas as suas searas - se reveste de princípios e garantias insculpidos na Constituição Federal. Dentre esses princípios, estão o do contraditório e da ampla defesa, bases de sustentação do devido processo legal, que possibilitam ao jurisdicionado recorrer a diversas

\footnotetext{
${ }^{23}$ Esse entendimento consta, por exemplo, dos pareceres presentes nos autos dos processos n.s 080704325.2020.4.05.8100 (7 $7^{\mathrm{a}}$. Vara da Seção Judiciário do Ceará); 0807450-31.2020.4.05.8100 (1 ${ }^{\mathrm{a}}$. Vara da Seção Judiciário do Ceará) e 0806938-48.2020.4.05.8100 (7ª . Vara da Seção Judiciário do Ceará).
} 
instâncias, retardando a efetivação do provimento judicial, inclusive aquele que condena a Fazenda Pública a restituir tributo indevidamente recolhido.

É certo que o processo civil brasileiro, objetivando maior celeridade, já impõe algumas limitações ao manejo de recursos, como, por exemplo, a impossibilidade de interposição de recurso extraordinário ou recurso especial quando a matéria já tenha sido julgada em sede de repercussão geral pelo Supremo Tribunal Federal ou no rito dos recursos repetitivos pelo Superior Tribunal de Justiça (art. 1030, I, "a" e "b" do CPC/2015). Essa regra se aplica, evidentemente, a matérias e processos tributários.

Contudo, mesmo com as limitações recursais já existentes na legislação, a ação de repetição de indébito (procedimento comum) e o mandado de segurança (procedimento especial), conquanto se tratem das principais medidas judiciais cabíveis para a restituição de tributos, apresentam características que podem retardar em demasia o acesso do contribuinte ao crédito tributário indevidamente pago. De fato, as peculiaridades das vias processuais atualmente disponíveis ao contribuinte, somadas às limitações contidas no próprio Código Tributário Nacional, fazem com que, embora o direito de restituição seja reconhecido, a tutela desse direito não seja efetivamente prestada. Isso se dá muito em função da impossibilidade de cumprimento provisório de sentença contra a Fazenda Pública e da inviabilidade de concessão de tutela provisória que autoriza a compensação tributária.

O procedimento especial sugerido por meio do presente trabalho pretende conferir maior eficiência aos provimentos judiciais relativos à repetição do indébito tributário, possibilitando, ao contribuinte, uma utilização mais ampla do instituto da compensação, seja em cumprimento provisório de título judicial, seja por meio de tutela provisória. A fixação de prazos mais exíguos e a extinção de alguns atos são medidas também essenciais a esse novo procedimento, pois visam, sobretudo, a reduzir a morosidade inerente ao processo judicial brasileiro, afinal, quem quer que tenha pagado algo indevidamente (seja essa prestação tributária ou não) tem direito a uma devolução célere.

As medidas ora propostas por meio desse procedimento especial de repetição de indébito (que deverá ser editado como lei complementar) não buscam desrespeitar as diretrizes do modelo constitucional de processo, muito antes pelo contrário. O objetivo é perseguir um equilíbrio entre contraditório, ampla defesa, efetividade e duração razoável do processo, a partir da ideia de que o processo se trata de um instrumento realizador da justiça. 


\section{REFERÊNCIAS}

BERNO, Cheryl. Restituição de Tributo Inconstitucional. 1ª ed. Curitiba: Juruá, 2005.

BRASIL. Código de Processo Civil, de 16 de março de 2015. Disponível em < http://www.planalto.gov.br/ccivil_03/_ato2015-2018/2015/lei/113105.htm>. Acesso em 10/06/21.

Código Tributário Nacional, de 25 de outubro de 1966. Disponível em < http://www.planalto.gov.br/ccivil_03/leis/15172compilado.htm>. Acesso em 10/06/21.

. Constituição (1988). Constituição da República Federativa do Brasil. Disponível em < http://www.planalto.gov.br/ccivil_03/constituicao/constituicao.htm.>. Acesso em $10 / 06 / 21$.

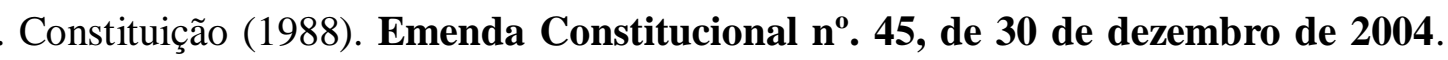

Disponível

em

<http://www.planalto.gov.br/ccivil_03/constituicao/emendas/emc/emc45.htm>. Acesso em 10/06/21.

Lei Complementar n. 104, de 10 de janeiro de 2001. Disponível em <http://www.planalto.gov.br/ccivil_03/leis/lcp/lcp104.htm>. Acesso em 12/06/21.

Lei Federal n. 6.830, de 22 de setembro de 1980. Disponível em: <http://www.planalto.gov.br/ccivil_03/leis/16830.htm>. Acesso em 12/06/21.

Lei Federal n. 8.383, de 30 de dezembro de 1991. Disponível em: <http://www.planalto.gov.br/ccivil_03/leis/18383.htm>. Acesso em 21/06/21.

. Lei Federal n. 8.397, de 06 de janeiro de 1992. Disponível em: <http://www.planalto.gov.br/ccivil_03/leis/L8397.htm>. Acesso em 12/06/21.

Lei Federal n. 9.430, de 27 de novembro de 1996. Disponível em < http://www.planalto.gov.br/ccivil_03/leis/19430.htm>. Acesso em 12/06/21.

. Lei Federal n. 12.016, de 07 de agosto de 2009. Disponível em <http://www.planalto.gov.br/ccivil_03/_ato2007-2010/2009/lei/112016.htm>. Acesso em $12 / 06 / 21$.

Superior Tribunal de Justiça. REsp 1895295/PE. Recorrente: Almecida Andrade Regis. Recorrido: União Federal. Relatora: Ministra Assusete Magalhães. Brasília, 24 de maio de $2021 . \quad$ Disponível em: <https://scon.stj.jus.br/SCON/GetInteiroTeorDoAcordao?num_registro=202002388822\&dt_p 
ublicacao=24/05/2021 $>$. Acesso em 13/06/21.

Superior Tribunal de Justiça. AgRg no REsp 1175542/RS. Agravante: Borrachas Urano Ltda. Recorrido: Estado do Rio Grande do Sul. Relator: Ministro Mauro Campbell Marques. Brasília, $1^{\circ}$. de setembro de 2010. Disponível em: <https://scon.stj.jus.br/SCON/GetInteiroTeorDoAcordao?num_registro=201000047390\&dt_p ublicacao=01/09/2010 > . Acesso em 13/06/21.

Superior Tribunal de Justiça. Súmula nº 212. In: . Súmulas. Brasília, 23 de maio de 2005. Disponível em: <https://www.stj.jus.br/docs_internet/revista/eletronica/stjrevista-sumulas-2010_15_capSumula212alterada.pdf $>$. Acesso em 13/06/2021.

Superior Tribunal de Justiça. Súmula $n^{\circ}$. 625. In: . Súmulas. Brasília, 23 de maio de 2005.2 Disponível em: <https://www.stj.jus.br/publicacaoinstitucional/index.php/sumstj/author/proofGalleyFile/5054 /5181\#: :text=O\%20pedido\%20administrativo\%20de\%20compensa\%C3\%A7\%C3\%A3o,jud icial\%20contra\%20a\%20Fazenda\%20P\%C3\%BAblica.>. Acesso em 13/06/2021.

- Supremo Tribunal Federal. RE 574.706/PR. Recorrente: Imcopa Importação, Exportação e Indústria de Óleos Ltda. Recorrido: União Federal. Relatora: Ministra Carmén Lúcia. Brasília, 02 de outubro de 2017. Disponível em: <https://jurisprudencia.stf.jus.br/pages/search/sjur374677/false>. Acesso em 13/06/21.

. Supremo Tribunal Federal. RE 608.482/RN. Recorrente: Estado do Rio Grande do Norte. Recorrido: Vanusa Fernandes da Araújo. Relator: Ministro Teori Zavascki. Brasília, 30 de outubro de 2014.2 Disponível em: $<$ https://redir.stf.jus.br/paginadorpub/paginador.jsp?docTP=TP\&docID=7088200>. Acesso em 13/06/21.

CÂMARA, Alexandre Freitas. O Novo Processo Civil Brasileiro. 3. ed. São Paulo: Atlas, 2017.

DANTAS, Paulo Roberto de Figueiredo. Direito Processual Constitucional. 8. ed. São Paulo: Saraiva Educação, 2018.

DONIZETTI, Elpídio. Curso Didático de Direito Processual Civil. 20 ed. São Paulo: Atlas, 2017.

DOS SANTOS, Eduardo R. Princípios Processuais Constitucionais. Salvador: Juspodivm, 2019.

FAZZALARI, Elio. Instituições de Direito Processual. Tradução da 8. ed. por Elaine Nassif. 
1. ed. Bookseller: Campinas, 2006

LAURENTIIS, Thais de. Restituição de Tributo Inconstitucional. São Paulo: Noesis, 2015. MACHADO, Hugo de Brito. Crimes Contra a Ordem Tributária. 4. ed. São Paulo: Atlas, 2015 .

MARDEN, Carlos. A Razoável Duração do Processo: o Fenômeno Temporal e o Modelo Constitucional Processual. 1. ed. Curitiba: Juruá Editora, 2015.

MARINONI, Luiz; ARENHART, Sérgio; MITIDIERO, Daniel. Curso de Processo Civil. Vol. 01. 5 ed. São Paulo: Thomson Reuters Brasil, 2020.

MENDES, Gilmar Ferreira; BRANCO Paulo Gustavo Gonet. Curso de Direito Constitucional. 12. ed. São Paulo: Saraiva, 2017.

NEVES, Daniel Amorim Assumpção. Manual de Direito Processual Civil. V. Único. 9. ed. Salvador: Juspodvim, 2017

NUNES, Cleucio Santos. Curso Completo de Direito Processual Tributário. 4. ed. São Paulo: Saraiva Educação, 2020.

PEIXOTO, Marco Aurélio Ventura; PEIXOTO, Renata Cortez Vieira. Fazenda Pública e Execução. Salvador: Juspodivm, 2018.

QUINTANILHA, Gabriel; PEREIRA, Felipe. Mandado de Segurança no Direito Tributário. 2. ed. São Paulo: Saraivajur, 2016.

SEGUNDO, Hugo de Brito Machado. Processo Tributário. 12. ed. São Paulo: Atlas, 2020.

THEODORO JÚNIOR, Humberto. Curso de Direito Processual Civil. Vol. 03. 50 ed. Rio de Janeiro: Forense, 2017

VERGUEIRO, Camila Campos et al. Processo Tributário Analítico. Coordenação Paulo Cesar Conrado. 1. ed. São Paulo: Noeses, 2016. 